\title{
BLACK GUILLEMOT SEEN IN REGINA
}

\section{FRANK BRAZIER, 2657 Cameron Street, Regina, Saskatchewan. S4T 2W5}

November 26, 1988, was a bitterly cold day with a strong, gusting, northeast wind. Blowing snow reduced visibility. The Canada. Geese remaining on Wascana Lake in Regina had kept an ice-free area, fairly large in extent, to the east of Spruce Island. Fred Lahrman (retired from the Saskatchewan Museum of Natural History) stood on the old abutment of the Broad Street bridge when he saw a strange bird among the geese. Several times he saw it dive in a manner he had not seen before.

The next day was a Sunday, a sunny day, $-22^{\circ} \mathrm{C}$ with a strong northwest wind. Trevor Herriot telephoned me to tell me of the strange bird. I went there at once and found Fred, and Robert Kreba, a know-ledgeable staff member of the museum, who had identified it as a Black Guillemot in winter plumage.

While we watched the guillemot, an adult Bald Eagle arrived. It perched on a tall spruce overlooking the open water but did not attack any of the birds, much to our relief.

When I returned home, I telephoned Stan Shadick in Saskatoon who brought a party to Regina in time to see the guillemot. I also telephoned Peter Whelan, who writes the bird column for the Globe and Mail and told him of our extraordinary visitor. I went to Moose Jaw after dinner and there telephoned Pat Kern who also brought a party of friends along to see the bird. A good number of Regina birders saw it and I learned that Brian Rainey had ventured out on the ice with a camera but he alarmed the bird and it flew off. The photographs turned out to be excellent, and put the Black Guillemot on the confirmed list of Saskatchewan birds.

Discussing the identification problem with Robert Kreba recently, I learned that he had relied mostly on Harrison to name it and to distinguish it from its relative the Pigeon Guillemot. ${ }^{1}$ The text stresses that the Black Guillemot has unmarked white secondary coverts (which show as conspicuous patches in the photographs) and has white axillaries and underwing coverts as opposed to the gray ones of the Pigeon Guillemot. The winter adult Black Guillemot head is mostly white, crown and lores are mottled with black, and upper parts mottled gray and white. The Pigeon Guillemot in winter is much the same, but its wing patches have black markings. For those without access to Harrison's book there is an excellent picture of a Black Guillemot in winter plumage in Robbins et al., page 149.2

Our Black Guillemot got an incidental mention in Blue Jay by a personal letter from Robert Kreba to Jacques Sirois, Canadian Wildlife Service; Yellowknife, NWT. It deserves better than that. It was the first species of the family Alcidae to be identified in Saskatchewan and it 
